\title{
Deactivation of Secondary Amine Catalysts via Aldol Reaction - Amine Catalysis Under Solvent-Free Conditions
}

\author{
Tobias Schnitzer and Helma Wennemers*
}

ETH Zürich, Laboratory of Organic Chemistry

Department of Chemistry and Applied Biosciences

Vladimir-Prelog-Weg 3, CH-8093 Zürich (Switzerland)

E-mail: Helma.Wennemers@org.chem.ethz.ch

\section{Supporting Information}

\section{Contents}

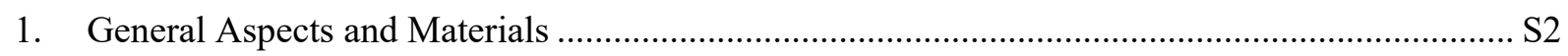

2. In-situ MS Analysis of the Conjugate Addition Reaction Catalyzed by 1 ................................... S3

3. Analytical Data of the Conjugate Addition Reaction Products $\mathbf{2 a}-\mathbf{2} \mathbf{j}$........................................... $\mathrm{S} 7$

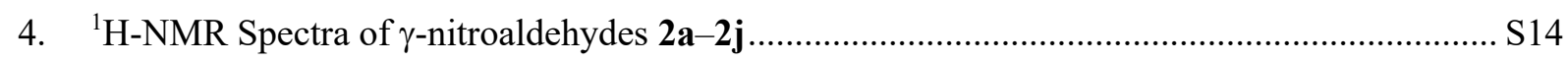

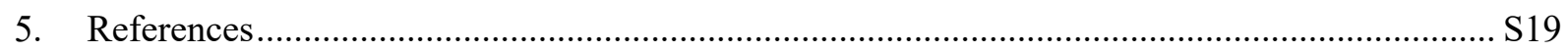




\section{General Aspects and Materials}

Reagents and materials were of the highest commercially available grade and used without further purification. Reactions were monitored by thin layer chromatography using Merck silica gel 60 F254 aluminium sheets. Visualization of the compounds was achieved by UVVis or $\mathrm{KMnO}_{4}$. Flash chromatography and plug filtrations were performed using silica gel 60 (particle size $0.040-0.063 \mathrm{~mm}, 200-400 \mathrm{mesh}$ ) manufactured by Fluka. Solvents for extraction and chromatography were of technical quality and distilled before use. ${ }^{1} \mathrm{H}$ and ${ }^{13} \mathrm{C} \mathrm{NMR}$ spectra were recorded on a Bruker DRX 400, a Bruker AV III 400 (400 MHz/100 MHz) or a Bruker AV III $600(600 \mathrm{MHz} / 150 \mathrm{MHz})$. All spectra were recorded at $25^{\circ} \mathrm{C}$, unless stated otherwise. Chemical shifts $(\delta)$ are reported in parts per million (ppm) relative to the signal of tetramethylsilane (TMS) using the residual solvent signals. SFC analyses were performed on an analytical SFC with a diode array detector ACQUITY-UPLCPDA from Waters using chiral stationary phase columns (Trefoil, AS, AD, IA, Whelk, IC, OD, OJ) $(150 \mathrm{~mm} \times 30 \mathrm{~mm})$ from Daicel or Waters under the reported conditions. HPLC analyses were performed on an analytical Ultimate 3000 HPLC system from Dionex with a diode array detector and chiral stationary phase columns (Daicel AD-H, Daicel AS-H, AY-H, OD-H or Daicel OJ-H). High-resolution electron ionization (HR-EI) mass spectra were measured on a Waters Micromass AutoSpec Ultima spectrometer. High-resolution MALDI spectra were acquired on a Bruker solariX 94 (ESI/MALDI-FT-ICR) and a Bruker UltraFlex II (MALDI-TOF) spectrometer. In-situ FT-IR spectroscopy was carried out on a ReactIR R4000 (SiComb probe) with a spectral range of 4000-650 $\mathrm{cm}^{-1}$. All measurements were performed at room temperature and spectra were recorded every minute. The peptidic catalysts $\mathbf{1}$ and $\mathbf{1 a}$ were prepared according to literature procedures. ${ }^{1,2}$ 


\section{In-situ MS Analysis of the Conjugate Addition Reaction Catalyzed by 1}

The TFA salt of $1(1 \mathrm{~mol} \%, 0.01 \mathrm{mmol}, 4.5 \mathrm{mg})$ and $(E)$-nitrostyrene (1.0 equiv., $1.0 \mathrm{mmol}$, $149.2 \mathrm{mg}$ ) were dissolved in $\mathrm{CHCl}_{3} /{ }^{2} \mathrm{PrOH}$ 9:1 (2 mL). N-methyl morpholine (1 mol\%, $0.01 \mathrm{mmol}, 1.1 \mu \mathrm{L})$ and butanal $(1.5$ equiv., $1.0 \mathrm{mmol}, 135.6 \mu \mathrm{L})$ were added and the reaction mixture was stirred for $1 \mathrm{~h}$. The reaction mixture was diluted with $\mathrm{MeOH}$ and analyzed by mass spectrometry $(\mathrm{ESI}+)$.

\section{Mass spectrum:}

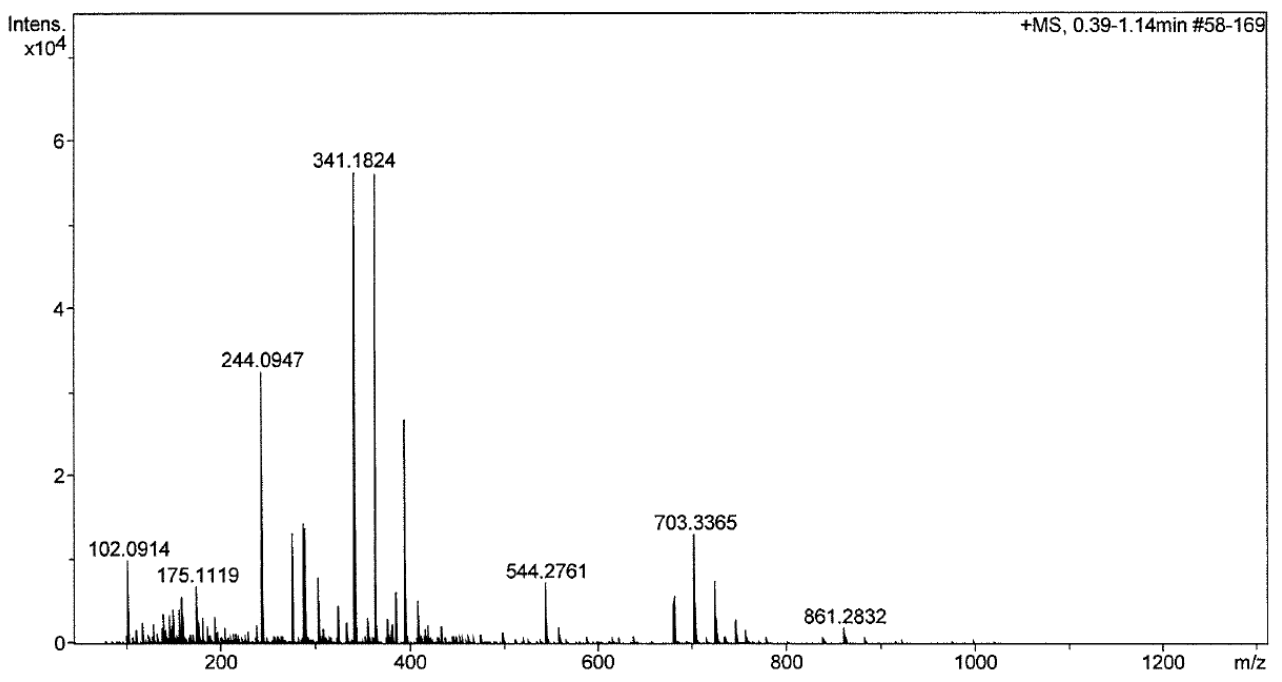

Peaks with the mass corresponding to the following structures were identified:

$\gamma$-nitroaldehyde 2a $\left([\mathrm{M}+\mathrm{Na}]^{+}=\mathbf{2 4 4 . 0 9 4 7} \mathrm{m} / \mathrm{z}\right):$<smiles>CCC(C=O)C(C[N+](=O)[O-])c1ccccc1</smiles>

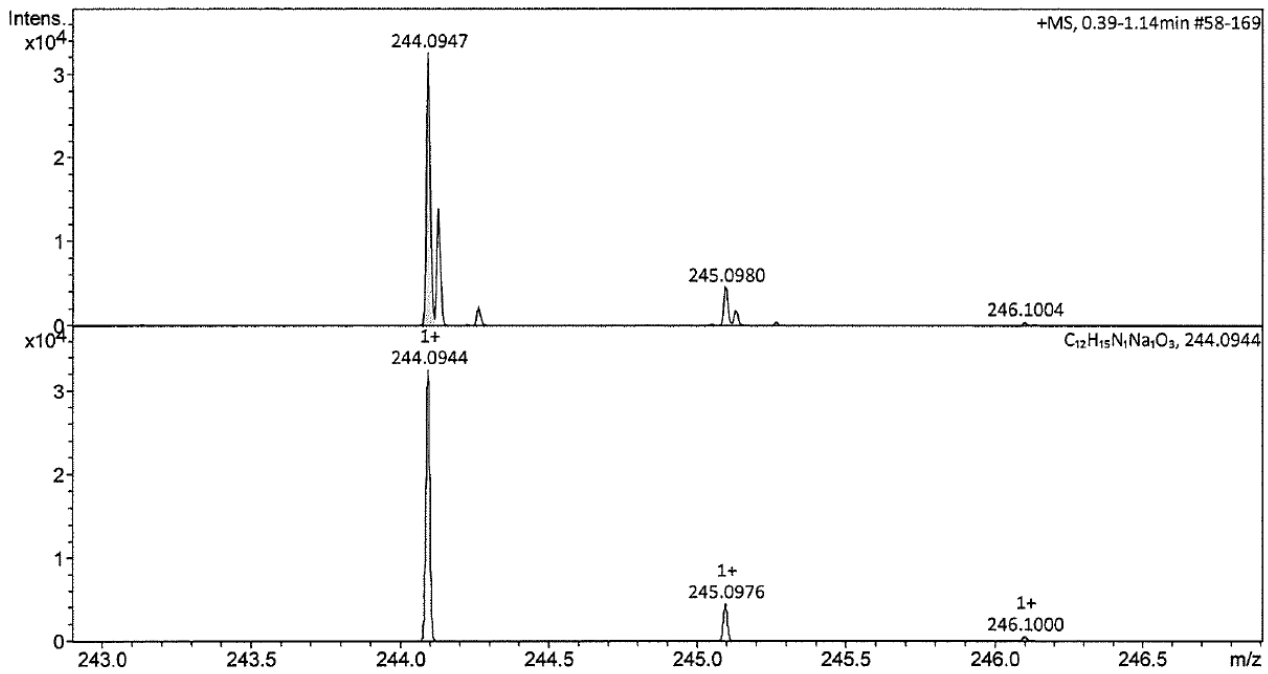


Peptide $1\left([\mathrm{M}+\mathrm{Na}]^{+}=363.1642 \mathrm{~m} / \mathrm{z}\right)$ :<smiles>NC(=O)C(CCC(=O)O)NC(=O)C1CCCN1C(=O)C1CCCN1</smiles>

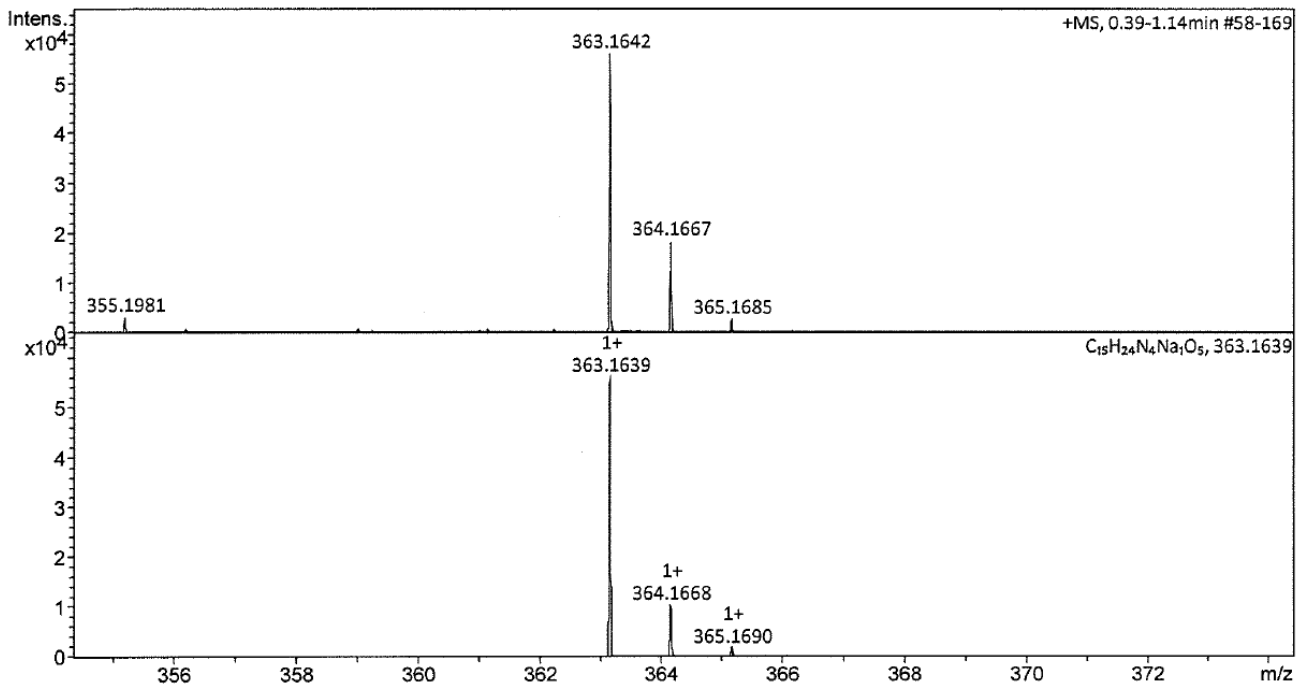

Peptide iminium (left) $\left([\mathrm{M}]^{+}\right)$and/or enamine intermediate $\left([\mathrm{M}+\mathrm{H}]^{+}\right)(395.2290 \mathrm{~m} / \mathrm{z})$ :<smiles>CCCN1CCCC1C(=O)N1CCCC1C(=O)NC(CCC(=O)O)C(N)=O</smiles><smiles>CC/C=C/N1CCCC1C(=O)N1CCCC1C(=O)N[C@H](CCC(=O)O)C(N)=O</smiles>

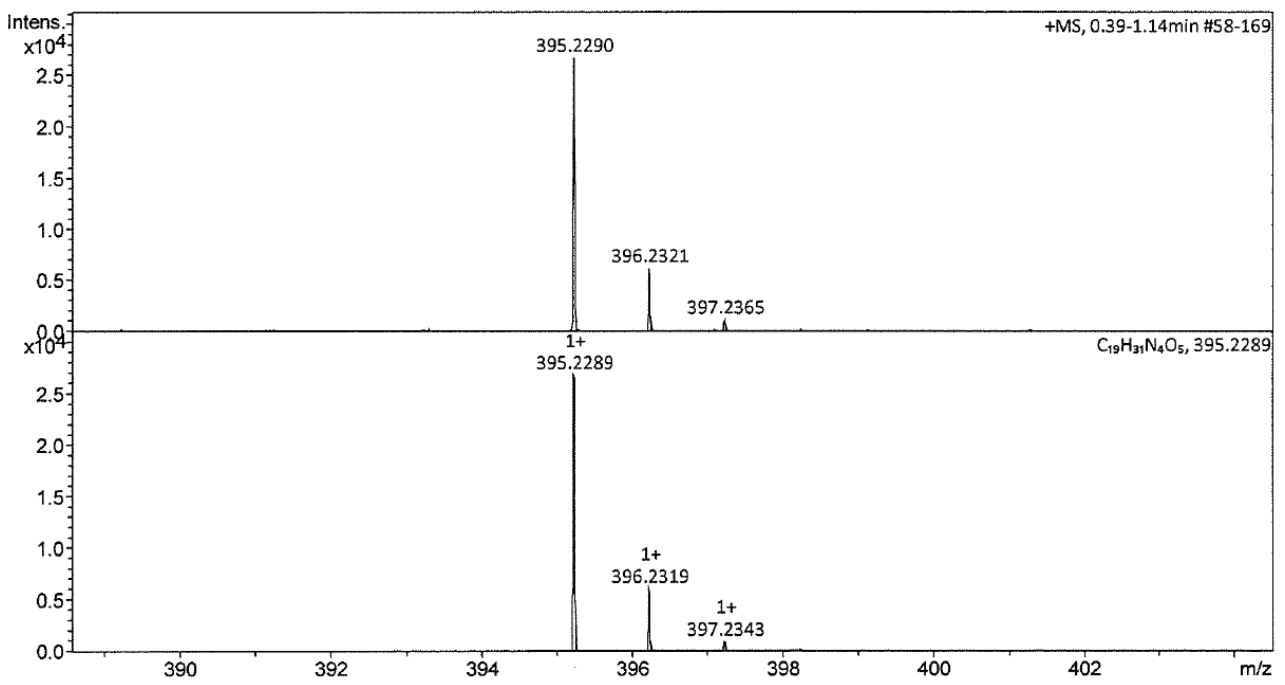


Peptide 1 and $\beta$-hydroxyaldehyde condensate $4\left([\mathrm{M}]^{+} /[\mathrm{M}+\mathrm{H}]^{+}=467.2858 \mathrm{~m} / \mathrm{z}\right)$ :<smiles>CCC(CC)C(O)CN1CCC[C@H]1C(=O)N1CCC[C@H]1C(=O)N[C@@H](CCC(=O)O)C(N)=O</smiles><smiles>CCC(CC)/C(=C\N1CCC[C@H]1C(=O)O)N1CCC[C@H]1C(=O)N[C@H](CCC(=O)O)C(N)=O</smiles>

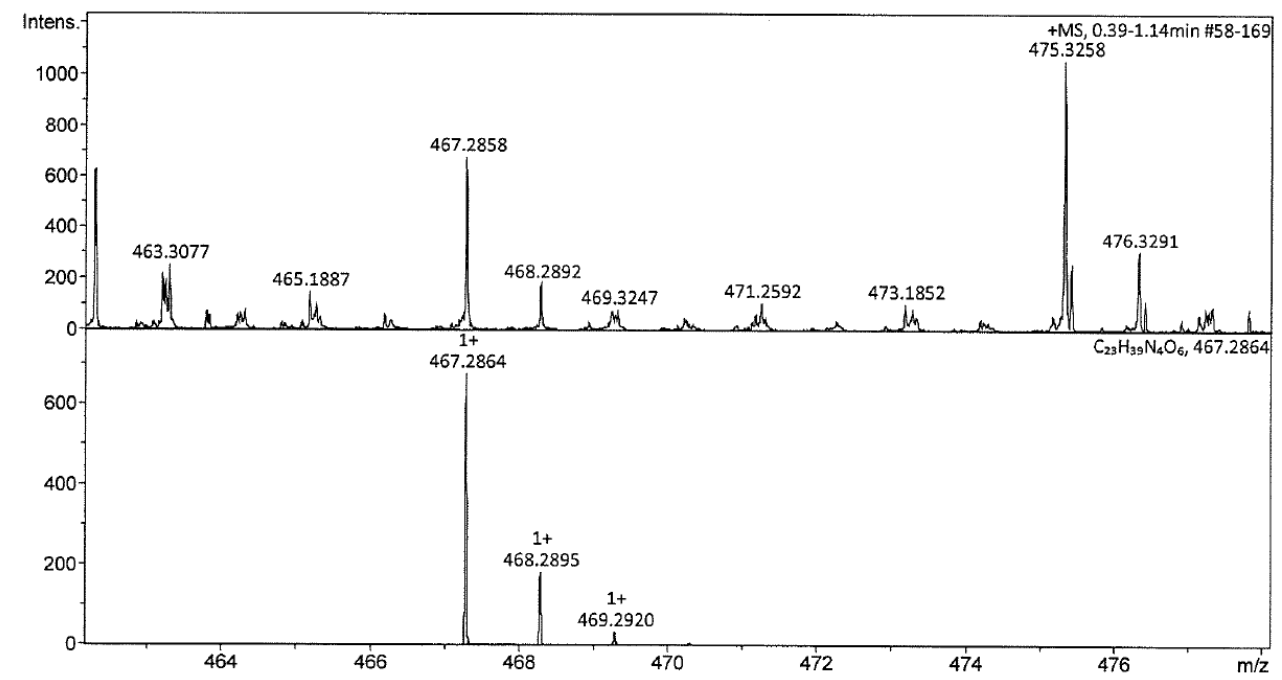

Note: The MS analysis was performed after diluting the sample that contained $1 \mathrm{~mol} \%$ of the peptidic catalyst by 100-1000 fold with $\mathrm{MeOH}$, conditions that were necessary for the MS analysis that do, however, also favor hydrolysis of enamines. The signal intensity of enamines 1-En and $\mathbf{4}$ is therefore low. 
Peptide condensate with product $2 \mathrm{a}\left([\mathrm{M}]^{+}=544.2761 \mathrm{~m} / \mathrm{z}\right)$ :<smiles></smiles>

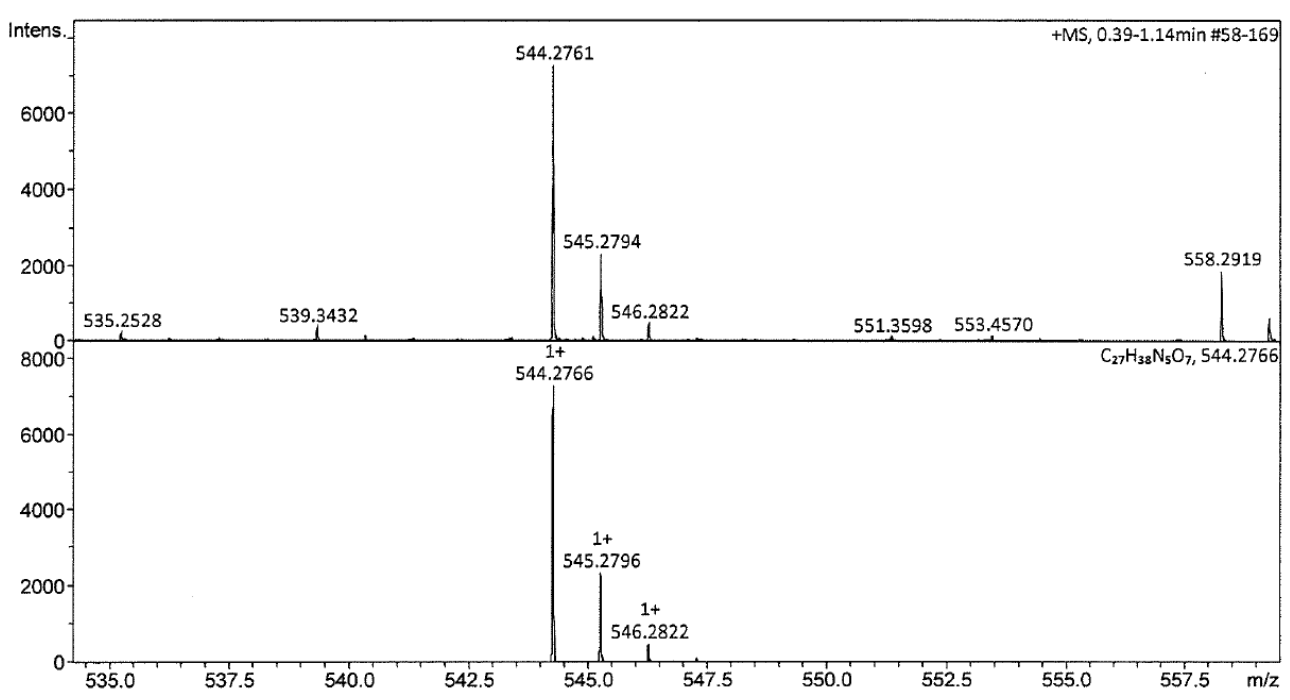

Note: Related compounds (e.g., enamine, cyclobutane, nitronate, dihydrooxazine- $N$-oxide) have the same mass and could therefore not be distinguished. 


\section{Analytical Data of the Conjugate Addition Reaction Products $\mathbf{2 a}-\mathbf{2 j}$}

\section{(2S,3R)-2-Ethyl-4-nitro-3-phenylbutanal 2a}

O Ph $\quad$ Yield $=95 \%, 61: 1$ d.r., 97\% ee (3 days reaction times). The analytical data are $\mathrm{NO}_{2}$ in agreement with previously published data. ${ }^{1}$

Ët 2a The reference SFC chromatogram of the racemic sample was reported in ref. 2.

diastereomeric ratio: $61: 1$

enantiomeric excess: $97 \%$
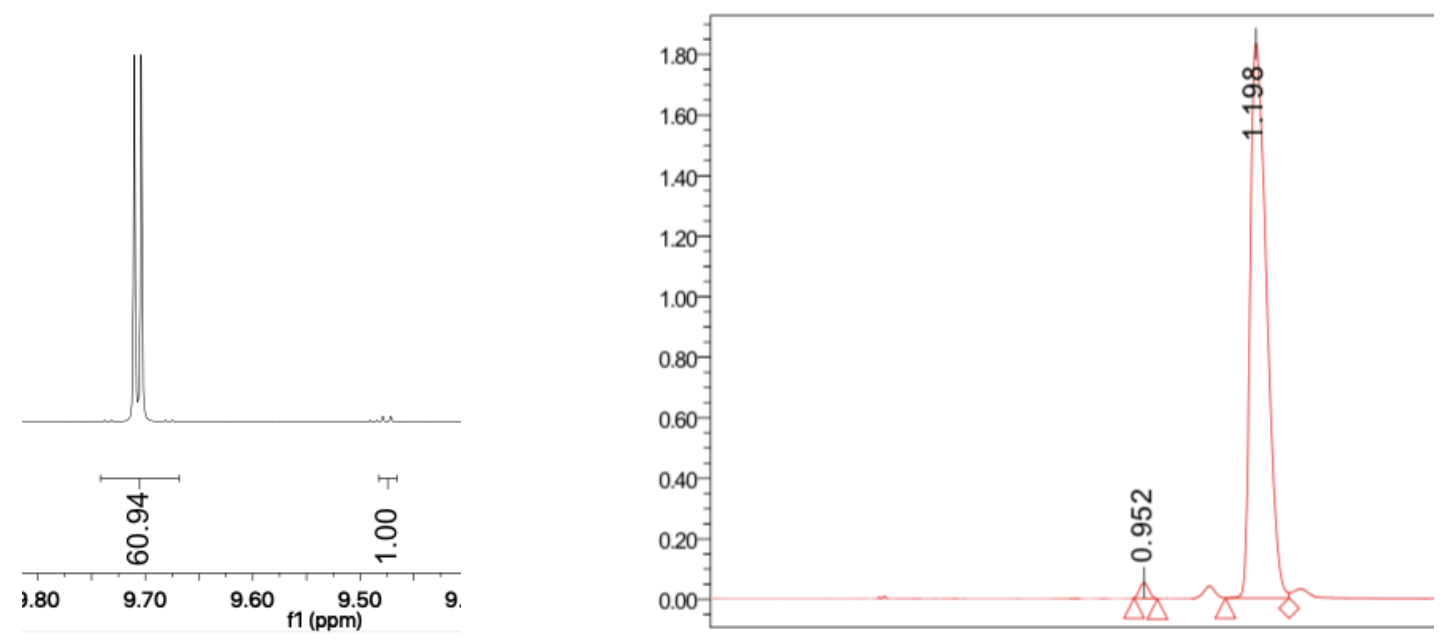


\section{Crystal Structure of 2a:}

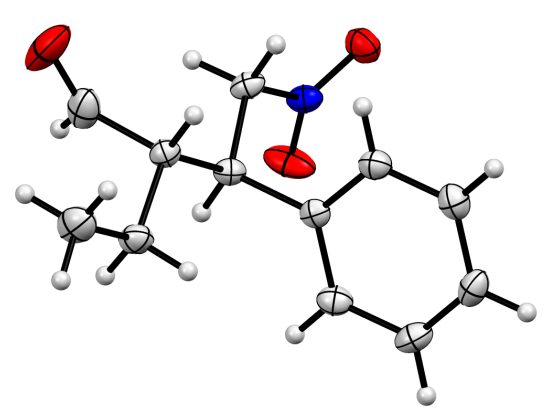

(Ellipsoid contour: 50\% probability)

\begin{tabular}{|c|c|}
\hline Identification code & w360817_1_1 \\
\hline Empirical formula & $\mathrm{C}_{12} \mathrm{H}_{15} \mathrm{NO}_{3}$ \\
\hline Formula weight & 221.25 \\
\hline Temperature/K & $100.0(1)$ \\
\hline Crystal system & orthorhombic \\
\hline Space group & $\mathrm{P} 2{ }_{1} 2{ }_{1}{ }_{1}$ \\
\hline $\mathrm{a} / \AA$ & $5.47770(10)$ \\
\hline $\mathrm{b} / \AA$ & $8.3194(2)$ \\
\hline $\mathrm{c} / \AA \AA$ & $25.6879(5)$ \\
\hline$\alpha /^{\circ}$ & 90 \\
\hline$\beta /{ }^{\circ}$ & 90 \\
\hline$\gamma /{ }^{\circ}$ & 90 \\
\hline Volume $/ \AA^{3}$ & $1170.63(4)$ \\
\hline $\mathrm{Z}$ & 4 \\
\hline$\rho_{\text {calc }} \mathrm{g} / \mathrm{cm}^{3}$ & 1.255 \\
\hline$\mu / \mathrm{mm}^{-1}$ & 0.743 \\
\hline $\mathrm{F}(000)$ & 472.0 \\
\hline Crystal size $/ \mathrm{mm}^{3}$ & $0.146 \times 0.089 \times 0.08$ \\
\hline Radiation & $\mathrm{CuK} \alpha(\lambda=1.54184)$ \\
\hline \multicolumn{2}{|c|}{$2 \Theta$ range for data collection $/{ }^{\circ} 6.882$ to 133.058} \\
\hline Index ranges & $-6 \leq \mathrm{h} \leq 5,-8 \leq \mathrm{k} \leq 9,-30 \leq 1 \leq 28$ \\
\hline Reflections collected & 6939 \\
\hline Independent reflections & $1953\left[\mathrm{R}_{\text {int }}=0.0396, \mathrm{R}_{\text {sigma }}=0.0334\right]$ \\
\hline Data/restraints/parameters & $1953 / 0 / 146$ \\
\hline Goodness-of-fit on $\mathrm{F}^{2}$ & 1.077 \\
\hline Final $\mathrm{R}$ indexes $[\mathrm{I}>=2 \sigma(\mathrm{I})]$ & $\mathrm{R}_{1}=0.0335, \mathrm{wR}_{2}=0.0834$ \\
\hline Final $\mathrm{R}$ indexes [all data] & $\mathrm{R}_{1}=0.0352, \mathrm{wR}_{2}=0.0844$ \\
\hline \multicolumn{2}{|c|}{ Largest diff. peak/hole / e $\AA^{-3} 0.12 /-0.19$} \\
\hline Flack parameter & $0.08(17)$ \\
\hline
\end{tabular}

A suitable crystal was selected and measured on a XtaLAB Synergy, Dualflex, Pilatus $300 \mathrm{~K}$ diffractometer. The crystal was kept at 100.0(1) K during data collection. Using Olex2, ${ }^{4}$ the structure was solved with the ShelXT ${ }^{5}$ structure solution program using Intrinsic Phasing and refined with the ShelXL ${ }^{6}$ refinement package using Least Squares minimization.

The crystal structure is deposited in the Cambridge Crystallographic Data Centre (CCDC Code: 1967754). 


\section{(2S,3R)-2-Methyl-4-nitro-3-phenylbutanal 2b}

O Ph $\quad$ Yield $=96 \%, 21: 1$ d.r., 98\% ee. The analytical data are in agreement with $\mathrm{NO}_{2}$ previously published data. ${ }^{1}$

Me $\quad$ 2b

The reference HPLC chromatogram of the racemic sample was reported in ref. 6.

diastereomeric ratio: $21: 1$

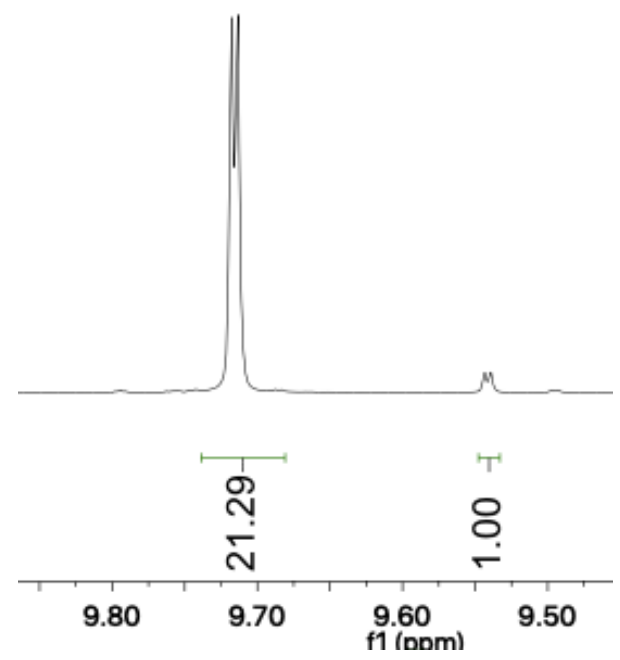

enantiomeric excess: $98 \%$

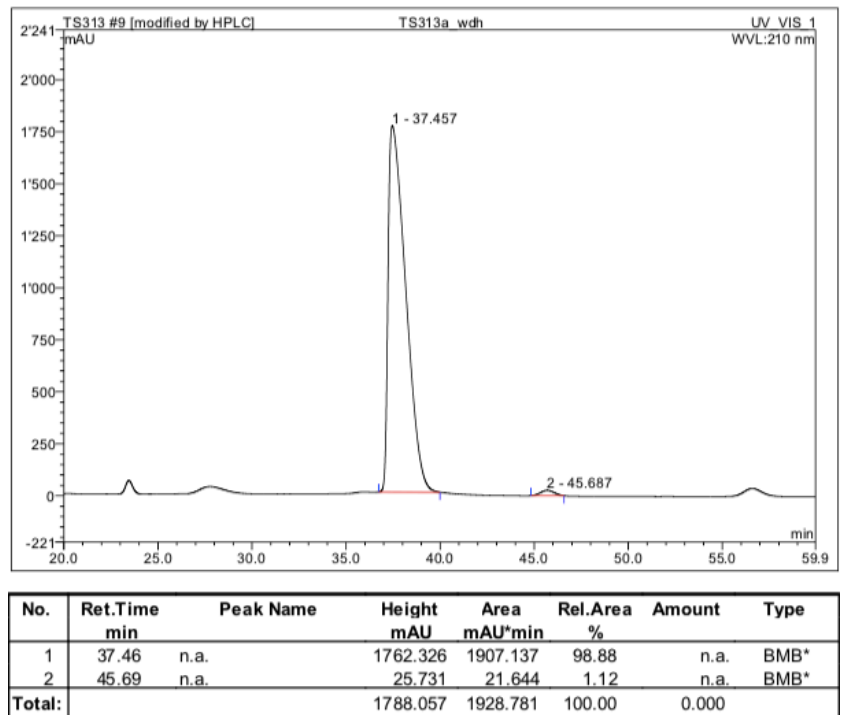

\section{(S)-2-((R)-2-Nitro-1-phenylethyl)hexanal 2c}

O Ph Yield $=>95 \%, 60: 1$ d.r., 98\% ee. The analytical data are in agreement $\mathrm{NO}_{2}$ with previously published data. ${ }^{1}$

${ }^{\mathrm{B}} \mathrm{Bu}$ 2C The reference HPLC chromatogram of the racemic sample was reported in ref. 1.

diastereomeric ratio: $60: 1$

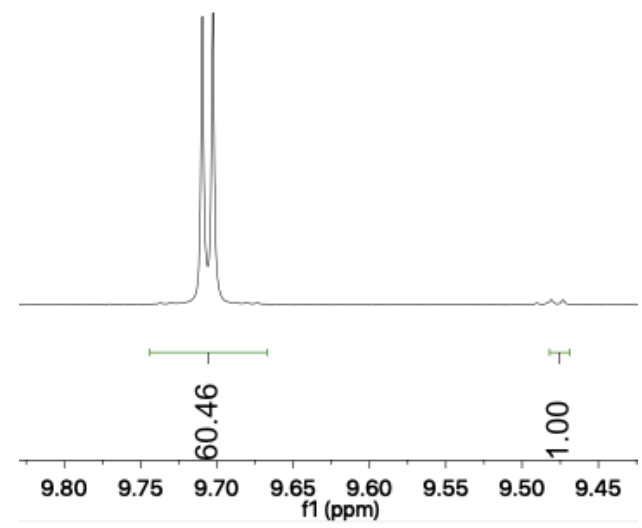

enantiomeric excess: $98 \%$

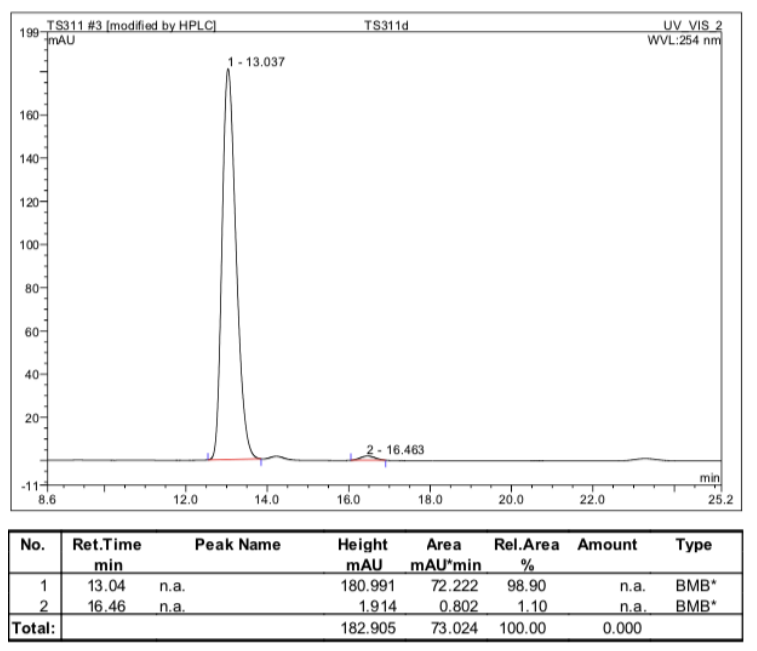




\section{(S)-2-((R)-2-Nitro-1-phenylethyl)pentanal 2d}

O Ph $\quad$ Yield $=97 \%, 33: 1$ d.r., 98\% ee. The analytical data are in agreement with $\mathrm{NO}_{2}$ previously published data. ${ }^{9}$

$\overline{\bar{n}}_{\operatorname{Pr}} \quad$ 2d

The reference HPLC chromatogram of the racemic sample was reported in ref. 1.

diastereomeric ratio: $33: 1$
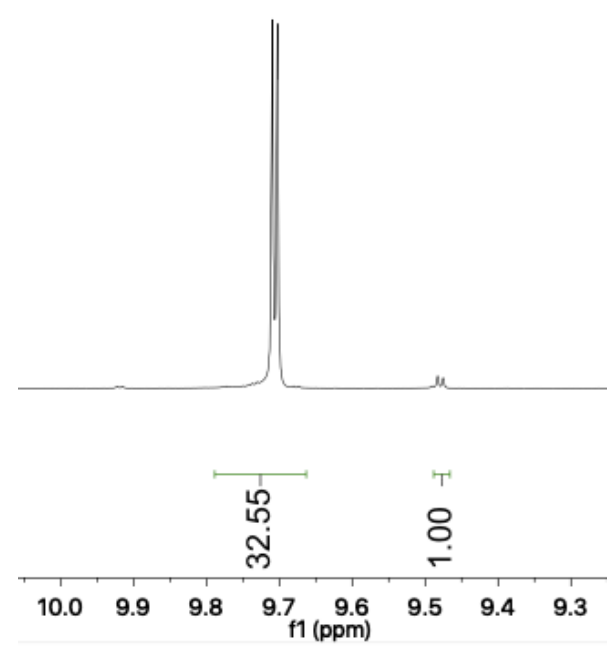

enantiomeric excess: $98 \%$

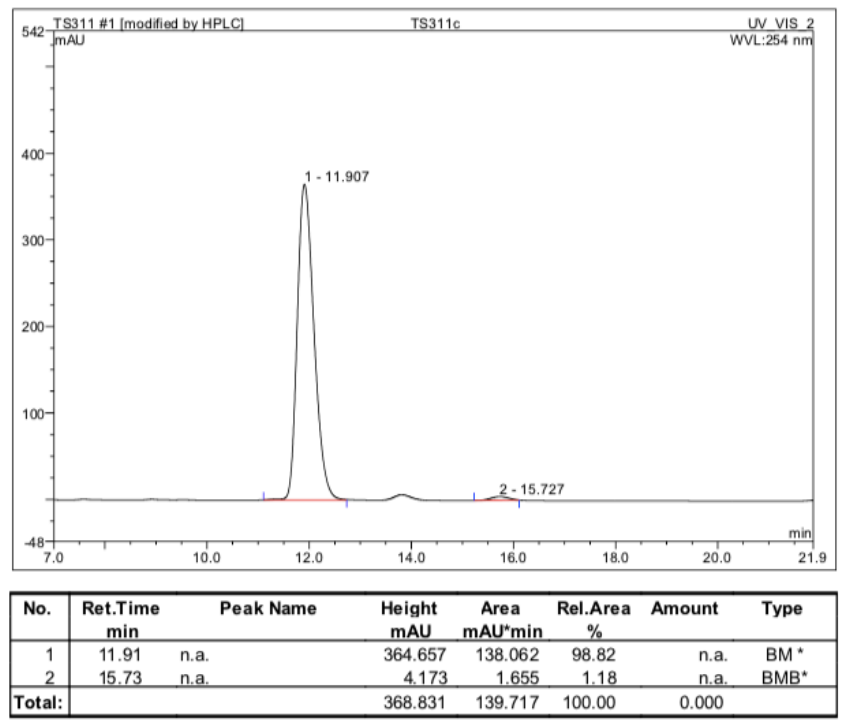

\section{(2S,3R)-2-Isopropyl-4-nitro-3-phenylbutanal 2e}

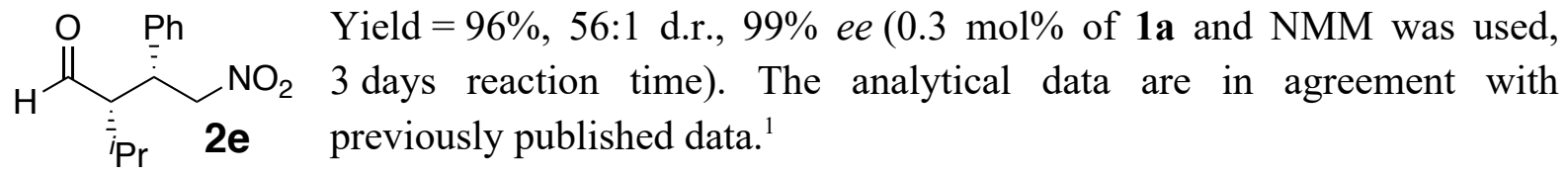

The reference HPLC chromatogram of the racemic sample was reported in ref. 7.

diastereomeric ratio: $56: 1$

enantiomeric excess: $99 \%$
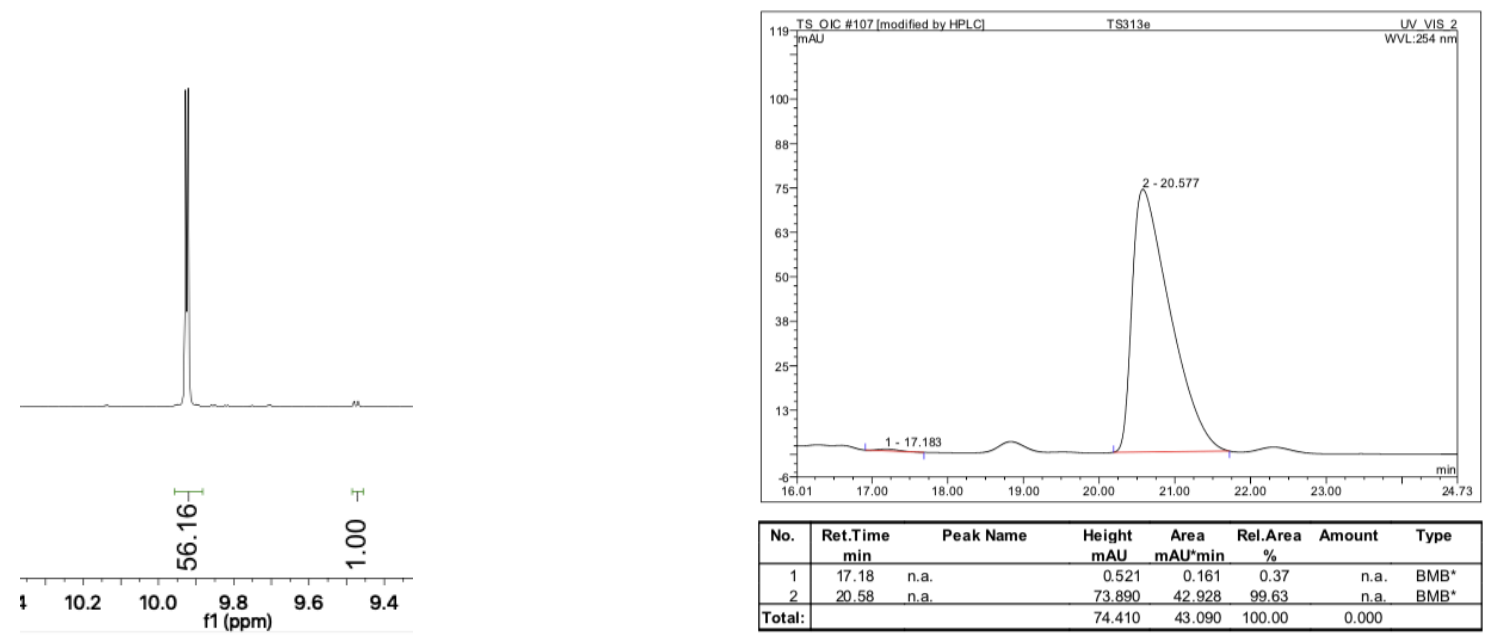


\section{(2S,3R)-2-Benzyl-4-nitro-3-phenylbutanal $2 f$}

O Ph $\quad$ Yield $=>95 \%, 37: 1$ d.r., 98\% ee. The analytical data are in agreement $\mathrm{NO}_{2}$ with previously published data. ${ }^{1}$

Bंn $2 f$

The reference HPLC chromatogram of the racemic sample was reported in ref. 1.

diastereomeric ratio: $37: 1$

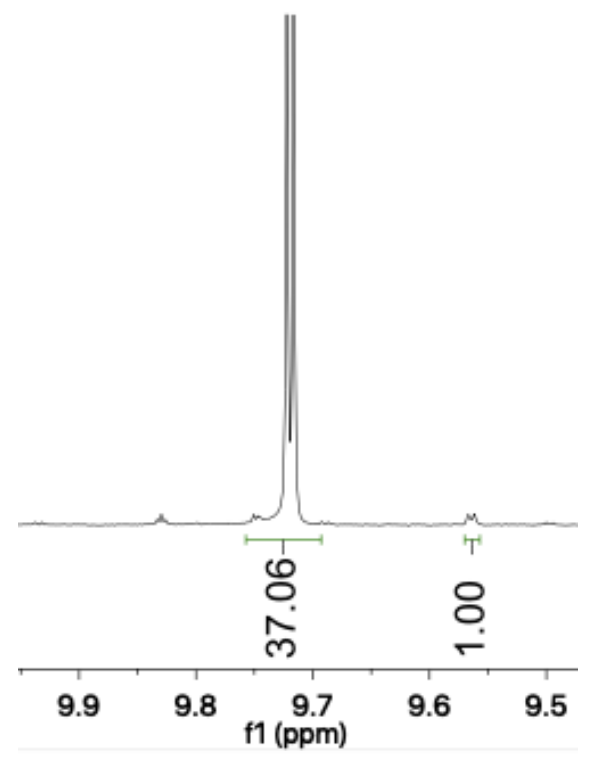

enantiomeric excess: $98 \%$

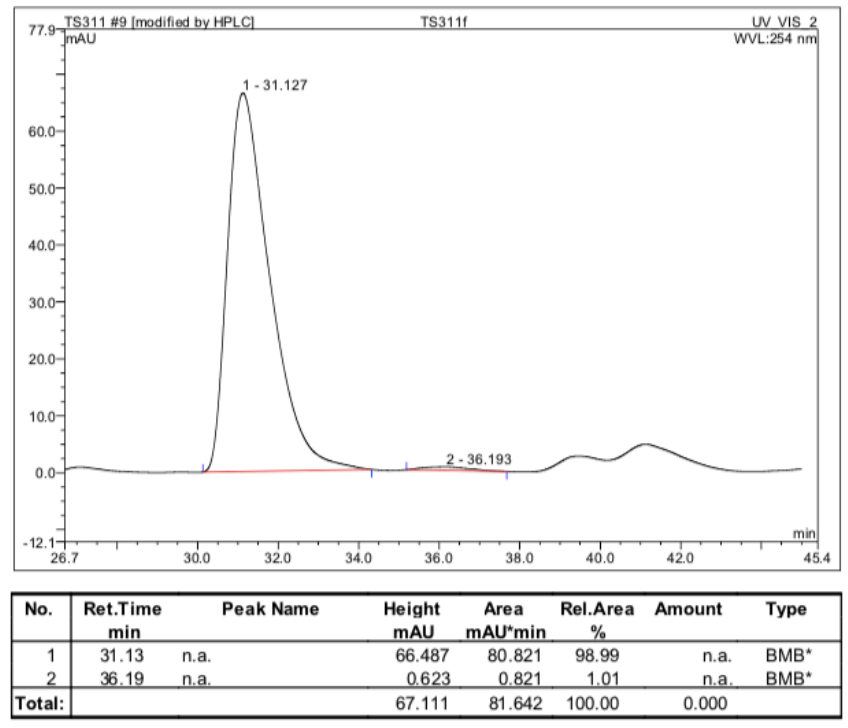

\section{(2S,3S)-2-Ethyl-3-(furan-2-yl)-4-nitrobutanal 2g}

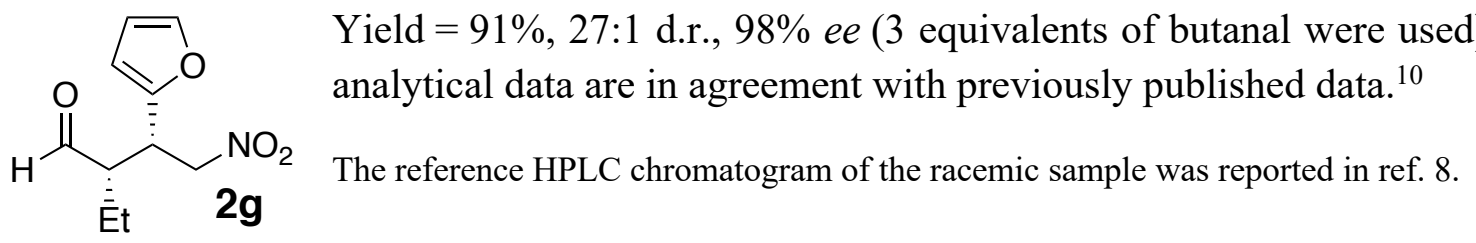

diastereomeric ratio: $27: 1$

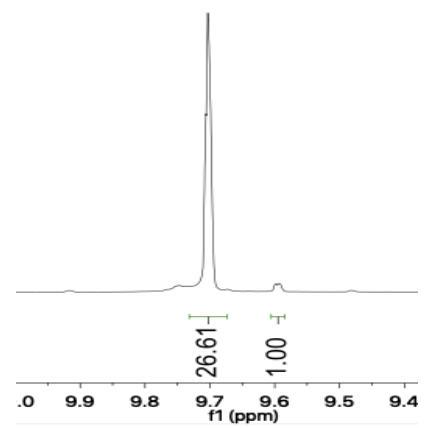

enantiomeric excess: $98 \%$

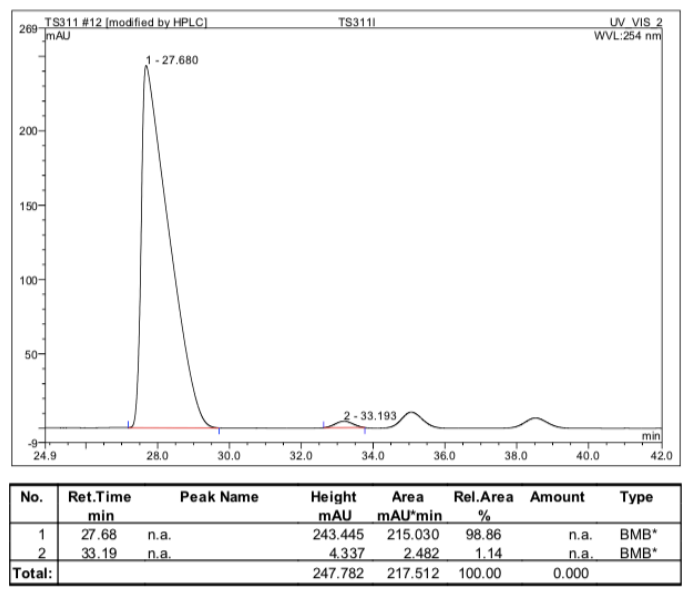




\section{(2S,3R)-2-Ethyl-3-(4-methoxyphenyl)-4-nitrobutanal $2 \mathrm{~h}$}

Yield $=94 \%, 41: 1$ d.r., $96 \%$ ee $(3$ equivalents of butanal were usect
days reaction time). The analytical data are in agreement with previon
published data. ${ }^{1}$

diastereomeric ratio: $41: 1$

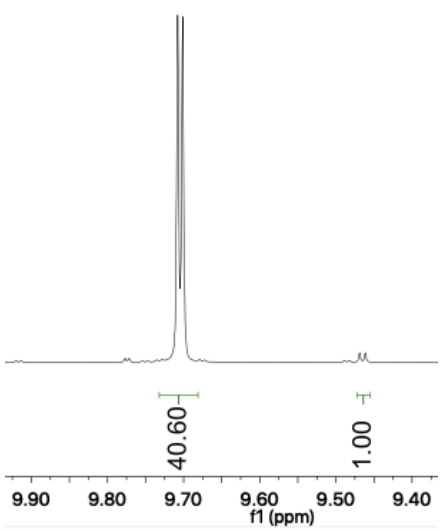

enantiomeric excess: $96 \%$

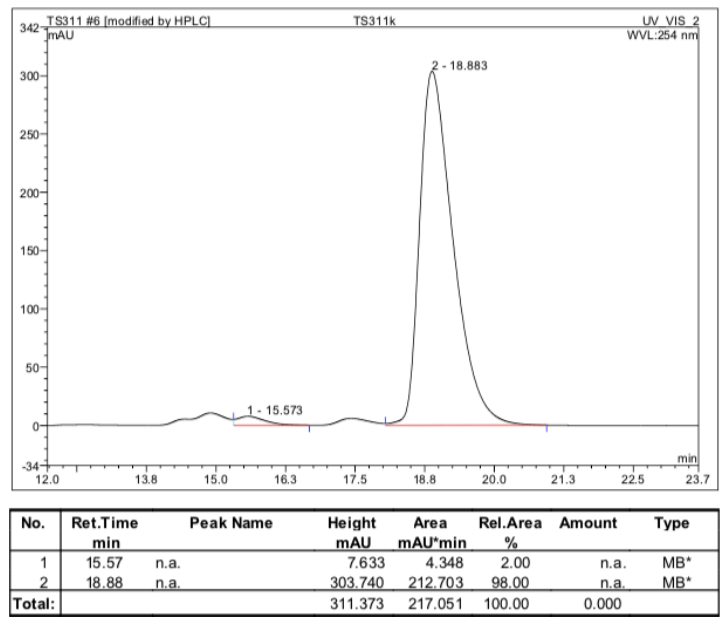

\section{(2S,3R)-2-Ethyl-3-(4-fluorophenyl)-4-nitrobutanal 2i}

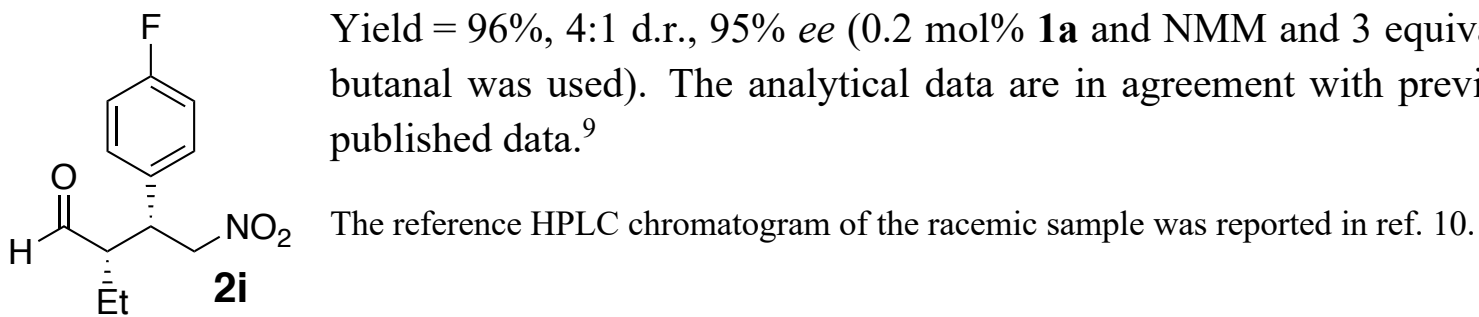

diastereomeric ratio: $41: 1$

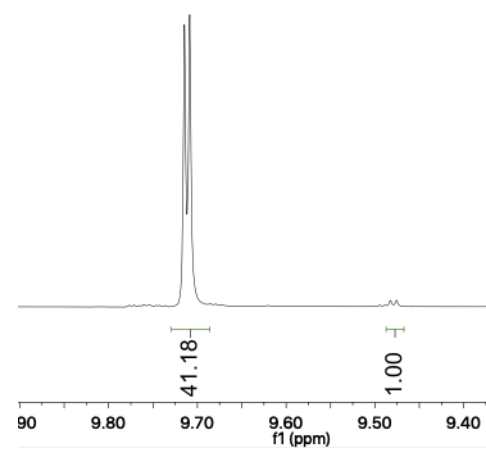

enantiomeric excess: $95 \%$

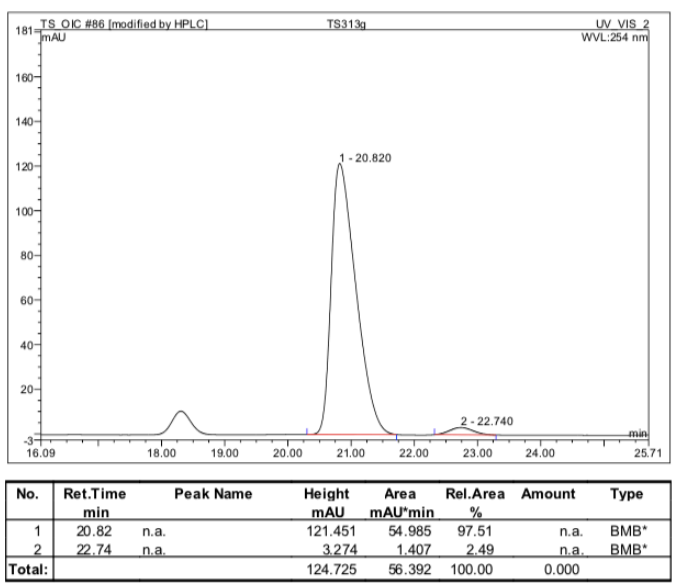




\section{(2S,3R)-3-(4-Chlorophenyl)-2-ethyl-4-nitrobutanal $2 \mathrm{j}$}

Yield $=96 \%, 46: 1$ d.r., $94 \%$ ee $(0.2$ mol\% $\mathbf{1 a}$ and $\mathrm{NMM}$ and
$\begin{aligned} & \text { equivalents butanal was used }) . \text { The analytical data are in agreement } \\ & \text { previously published data. }\end{aligned}$

diastereomeric ratio: $46: 1$

enantiomeric excess: $94 \%$
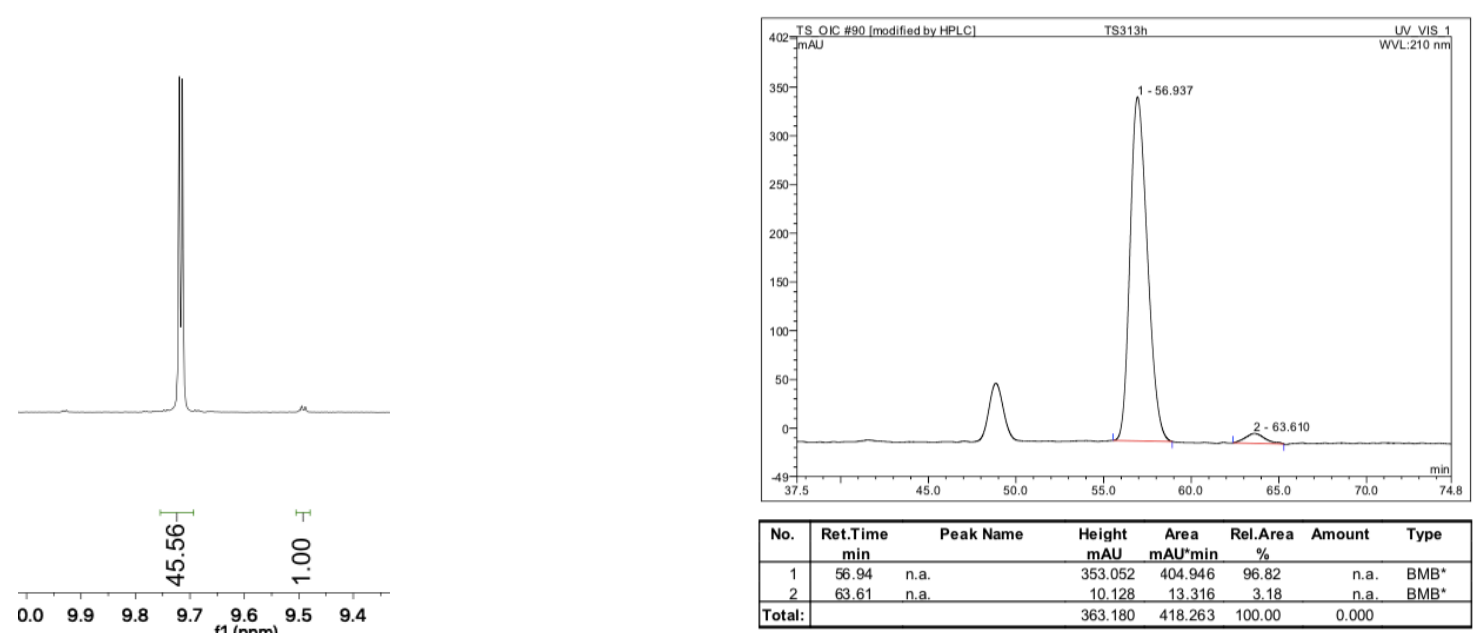


\section{4. $\quad{ }^{1} \mathbf{H}-N M R$ Spectra of $\gamma$-nitroaldehydes $2 \mathrm{a}-2 \mathbf{j}$}

${ }^{1} \mathrm{H}$ NMR (400 MHz, $\left.\mathrm{CDCl}_{3}\right)$ of $\mathbf{2 a}$

Yู

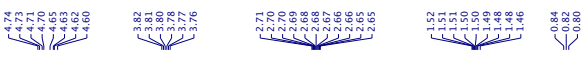<smiles>CCC(C=O)C(C[N+](=O)[O-])c1ccccc1</smiles>

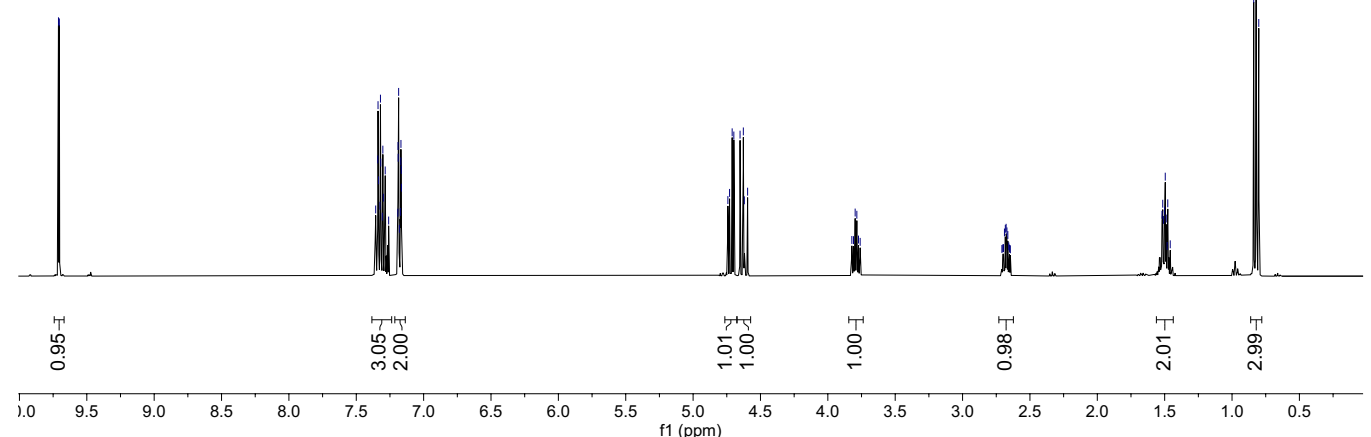

${ }^{1} \mathrm{H}$ NMR $\left(400 \mathrm{MHz}, \mathrm{CDCl}_{3}\right)$ of $\mathbf{2 b}$

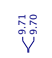

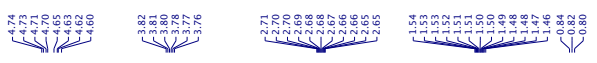<smiles>C[C@H](C=O)C(C[N+](=O)[O-])c1ccccc1</smiles>

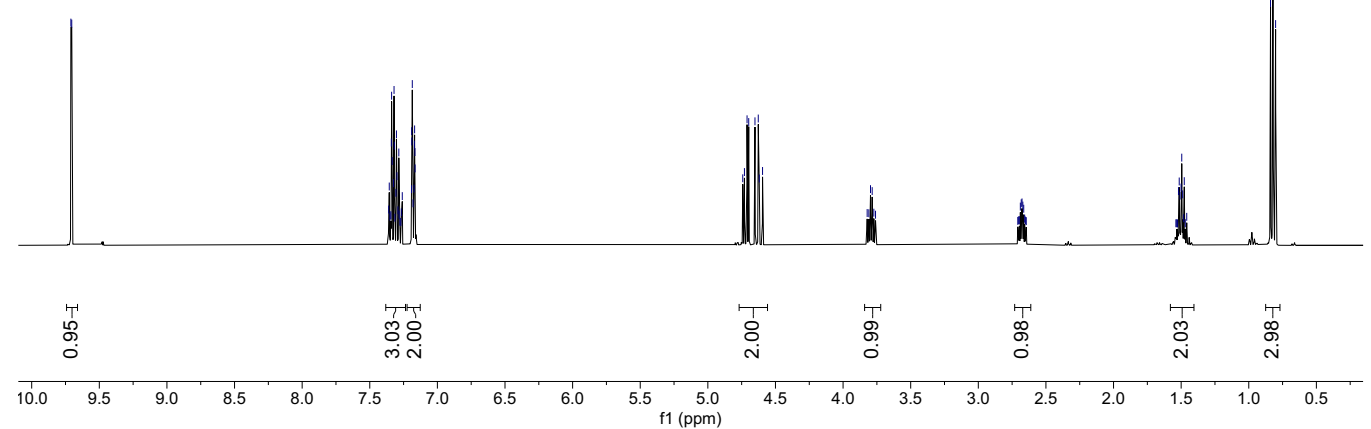


${ }^{1} \mathrm{H}$ NMR (400 MHz, $\mathrm{CDCl}_{3}$ ) of $\mathbf{2 c}$

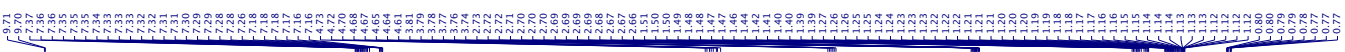<smiles>CC(C)(C)C(C=O)C(C[N+](=O)[O-])c1ccccc1</smiles>

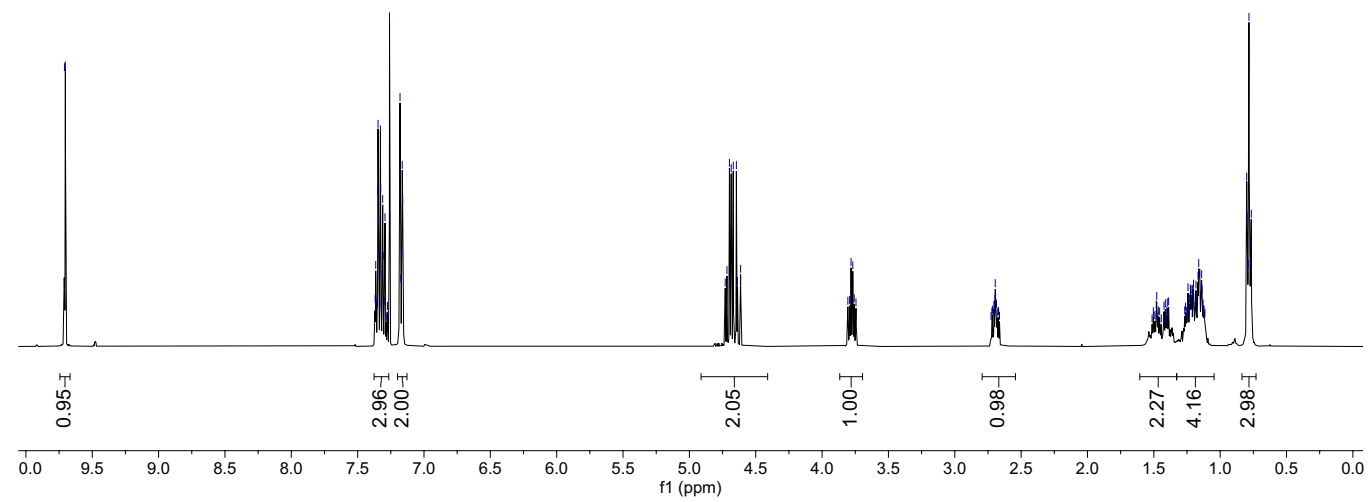

${ }^{1} \mathrm{H}$ NMR $\left(400 \mathrm{MHz}, \mathrm{CDCl}_{3}\right)$ of $\mathbf{2 d}$

Y Fo<smiles>CCCC(C=O)C(C[N+](=O)[O-])c1ccccc1</smiles>

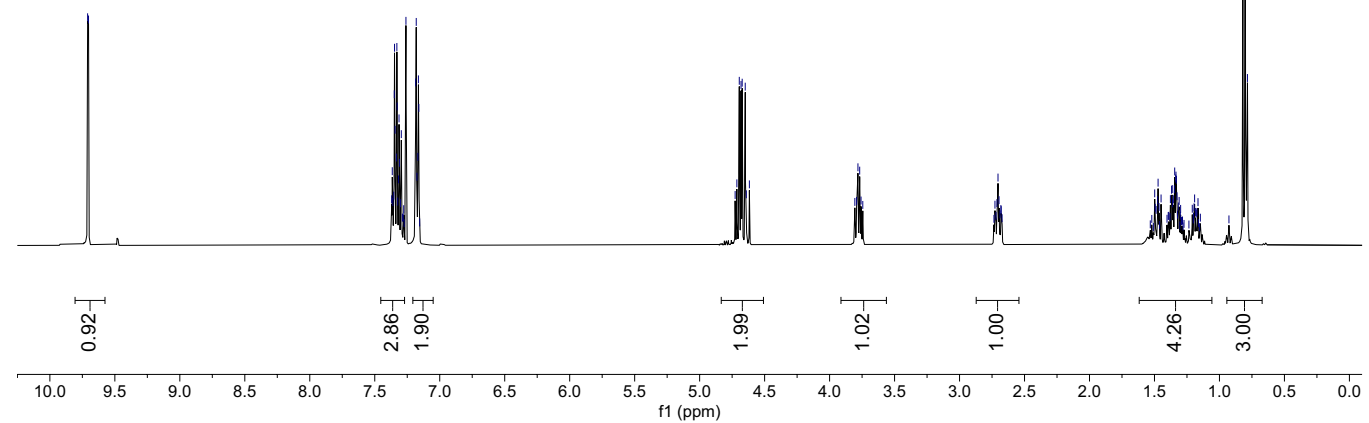


${ }^{1} \mathrm{H}$ NMR (400 MHz, $\mathrm{CDCl}_{3}$ ) of $\mathbf{2 e}$

พูa

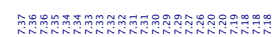

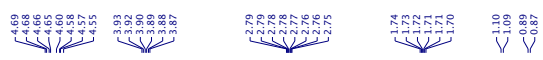<smiles>CCCC(C=O)C(C[N+](=O)[O-])c1ccccc1</smiles>

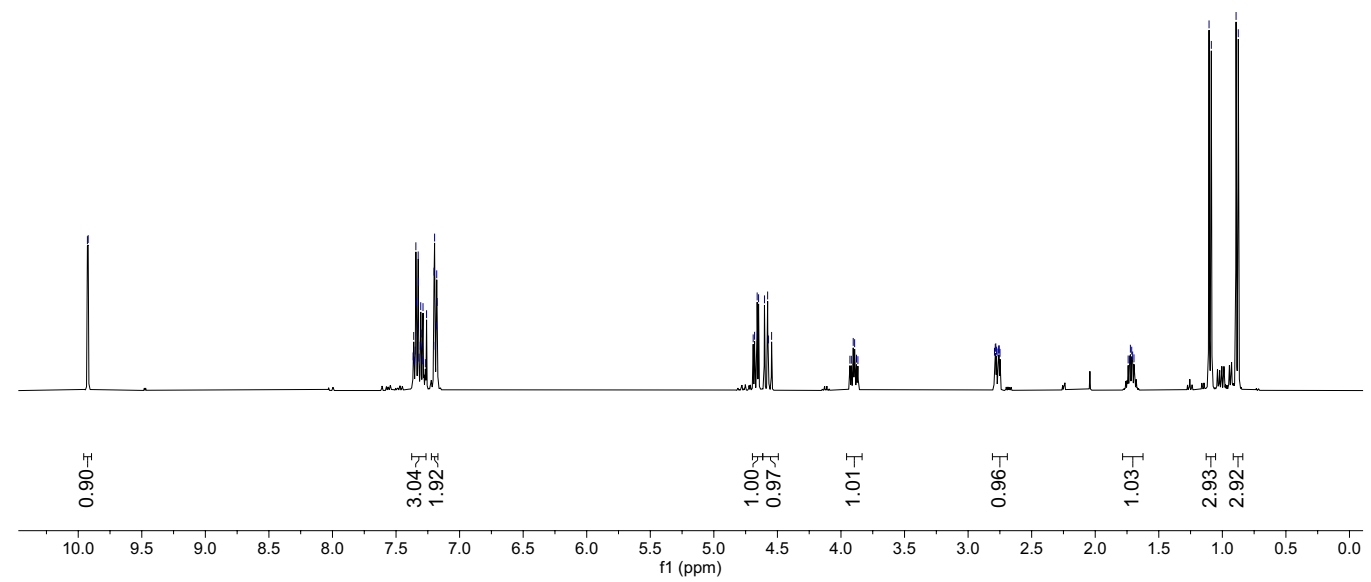

${ }^{1} \mathrm{H}$ NMR $\left(400 \mathrm{MHz}, \mathrm{CDCl}_{3}\right)$ of $\mathbf{2 f}$

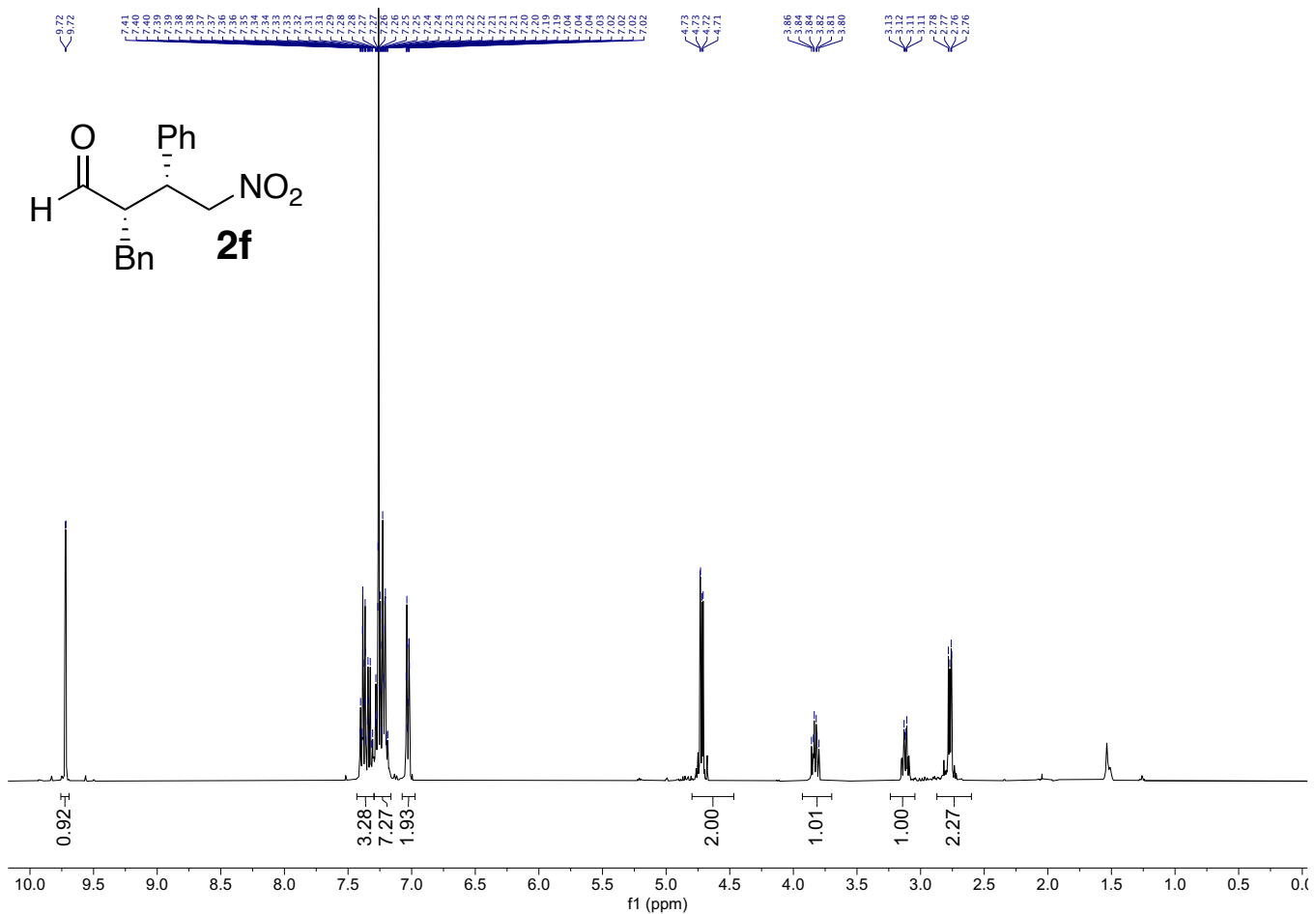


${ }^{1} \mathrm{H}$ NMR (400 MHz, $\mathrm{CDCl}_{3}$ ) of $\mathbf{2 g}$

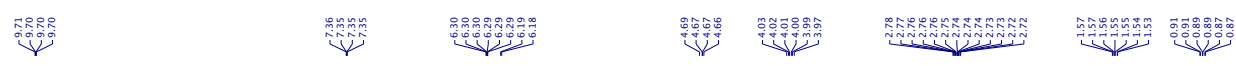<smiles>CCC(C=O)[C@H](C[N+](=O)[O-])c1ccco1</smiles>

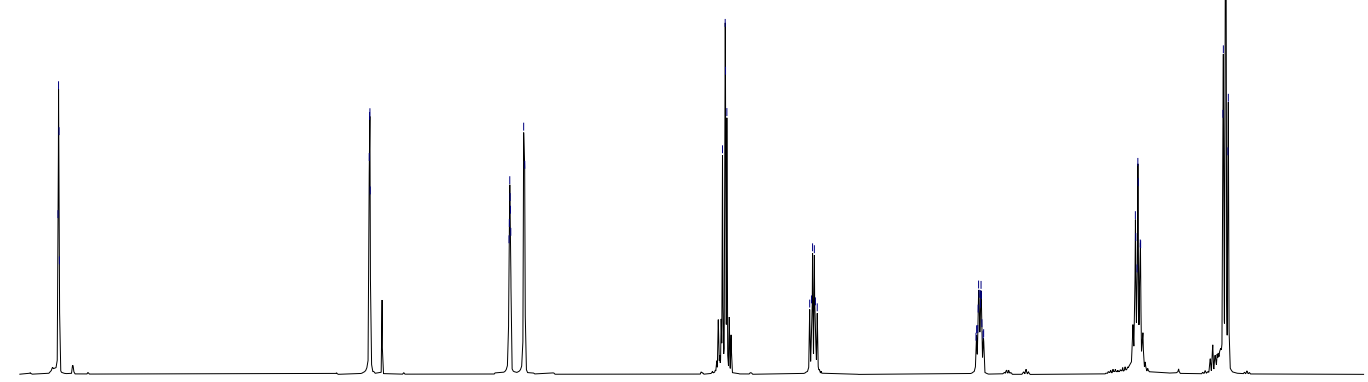

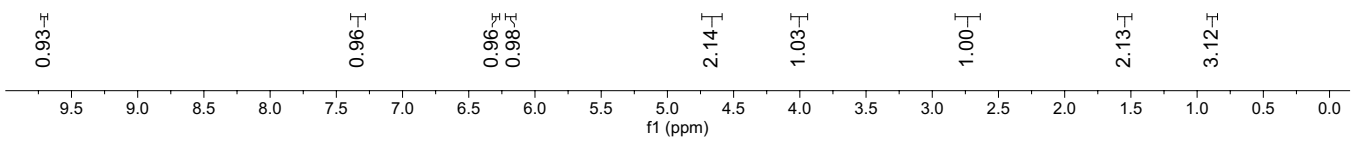

${ }^{1} \mathrm{H}$ NMR $\left(400 \mathrm{MHz}, \mathrm{CDCl}_{3}\right)$ of $\mathbf{2 h}$

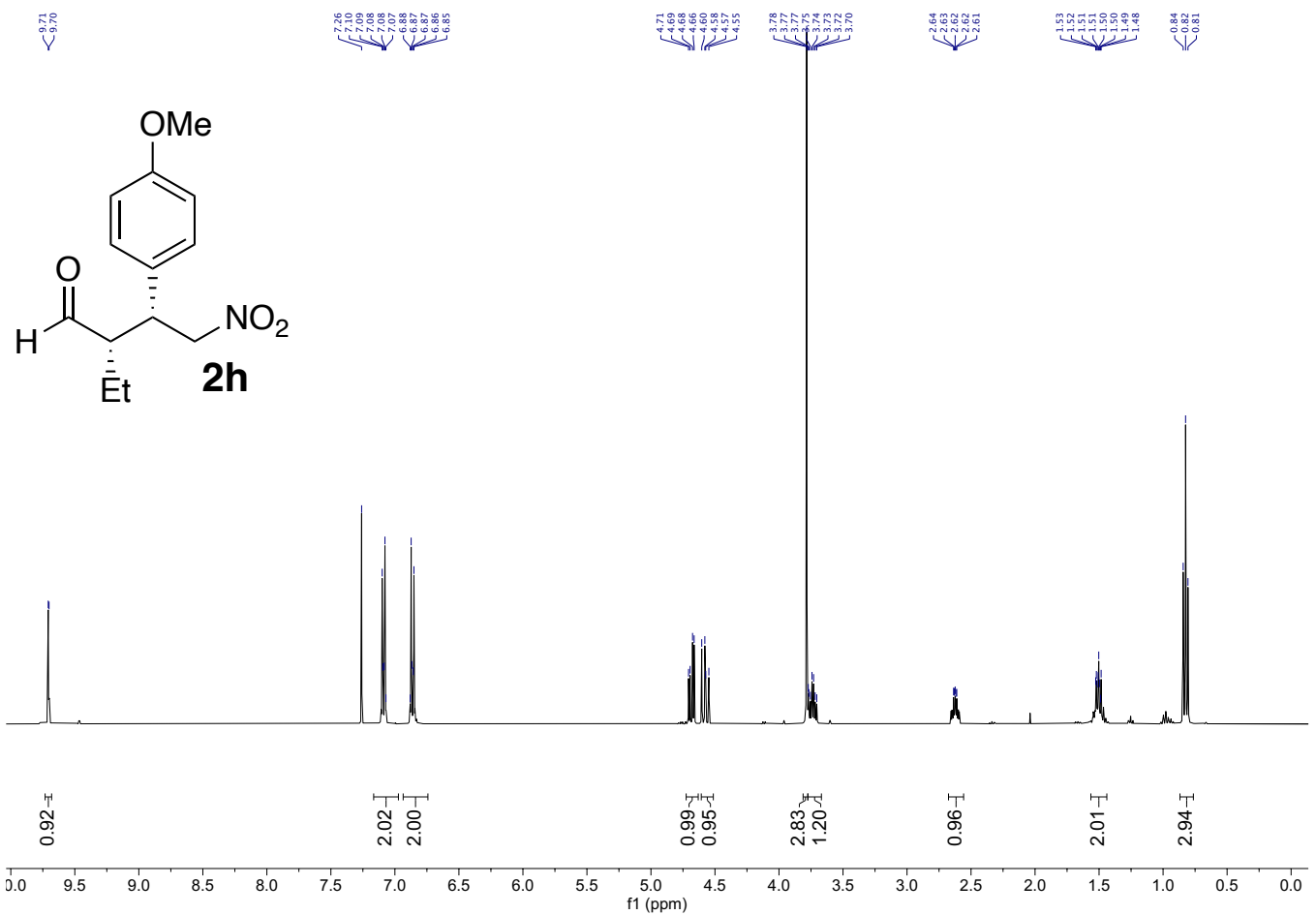


${ }^{1} \mathrm{H}$ NMR (400 MHz, $\mathrm{CDCl}_{3}$ ) of $\mathbf{2 i}$

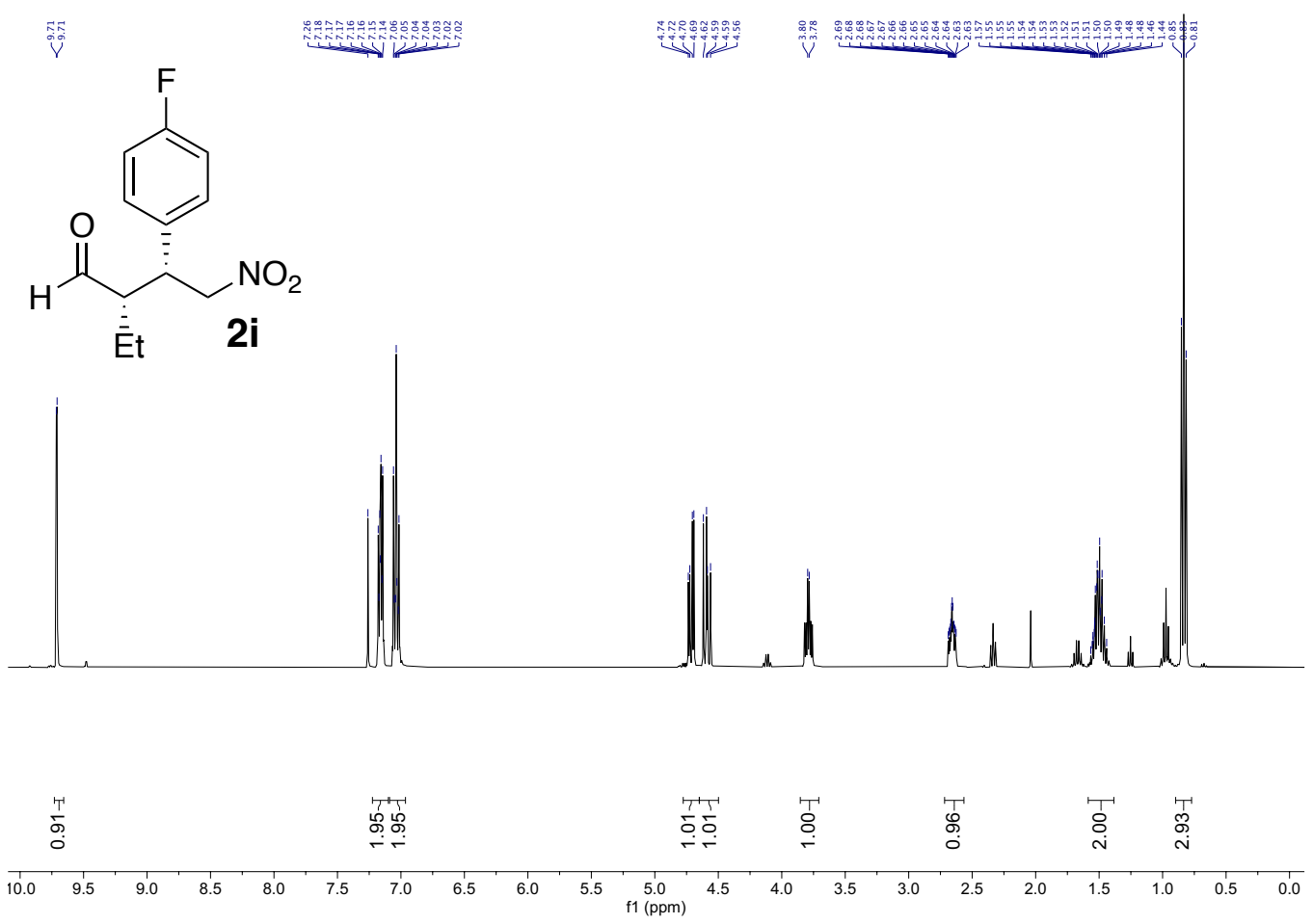

${ }^{1} \mathrm{H}$ NMR $\left(400 \mathrm{MHz}, \mathrm{CDCl}_{3}\right)$ of $\mathbf{2} \mathbf{j}$

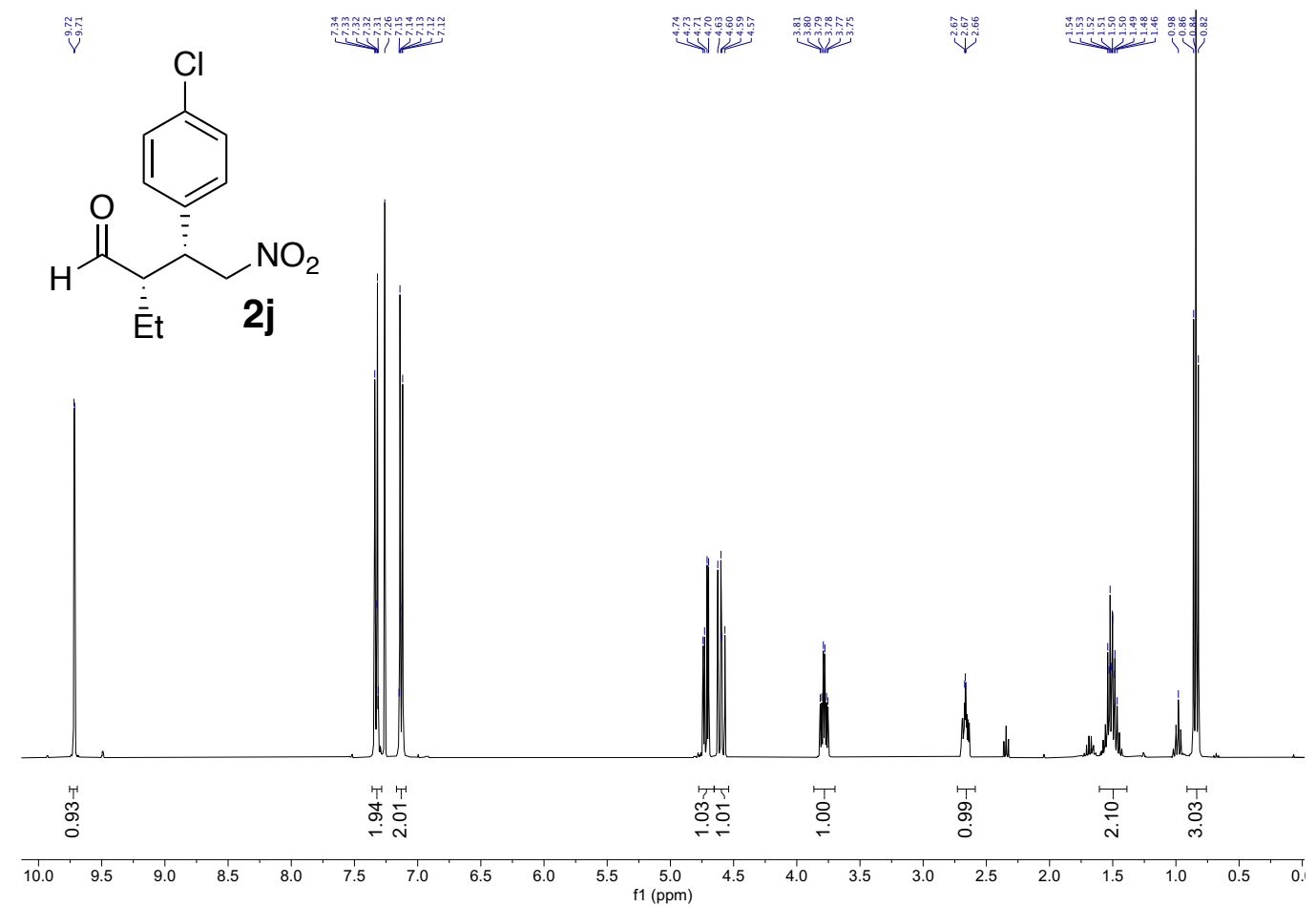




\section{References}

1. Wiesner, M.; Neuburger, M.; Wennemers, H. Tripeptides of the Type H-D-Pro-ProXaa- $\mathrm{NH}_{2}$ as Catalysts for Asymmetric 1,4-Addition Reactions: Structural Requirements for High Catalytic Efficiency. Chem. Eur. J. 2009, 15, 10103.

2. Schnitzer, T.; Wennemers, H. Influence of the Trans/Cis Conformer Ratio on the Stereoselectivity of Peptidic Catalysts. J. Am. Chem. Soc. 2017, 139, 15356.

3. Dolomanov, O. V.; Bourhis, L. J.; Gildea, R. J.; Howard, J. A. K.; Puschmann, H. OLEX2: a complete structure solution, refinement and analysis program. J. Appl. Cryst. 2009, 42, 339.

4. Sheldrick, G. M. SHELXT - Integrated space-group and crystal-structure determination. Acta Cryst. A, 2015, 71, 3 .

5. Sheldrick, G.M. Crystal structure refinement with SHELXL. Acta Cryst. C, 2015, 71, 3.

6. Lombardo, M.; Chiarucci, M.; Quintavalla, A.; Trombini, C. Highly Efficient IonTagged Catalyst for the Enantioselective Michael Addition of Aldehydes to Nitroalkenes. Adv. Synth. Catal. 2005, 351, 2801.

7. Duschmale, J.; Kohrt, S.; Wennemers, H. Peptide catalysis in aqueous emulsions. Chem. Commun. 2014, 50, 8109.Wang, Y.; Li, D.; Lin, J.; Wei, K. Organocatalytic asymmetric Michael addition of aldehydes and ketones to nitroalkenes catalyzed by adamantoyl 1-prolinamide. RSC Adv. 2015, 5, 5863.

8. Wiesner, M.; Revell, J. D.; Wennemers, H. Tripeptides as efficient asymmetric catalysts for 1,4-addition reactions of aldehydes to nitroolefins - a rational approach. Angew. Chem. Int. Ed. 2008, 47, 1871.

9. Cortes-Clerget, M.; Gager, O.; Monteil, M.; Pirat, J.-L.; Migianu-Griffoni, E.; Deschamp, J.; Lecouvey, M. Novel Easily Recyclable Bifunctional Phosphonic Acid Carrying Tripeptides for the Stereoselective Michael Addition of Aldehydes with Nitroalkenes. Adv. Synth. Catal. 2016, 358, 34. 